\title{
Modification on Synthesis of Mixed Ligand Chelates by Using Di- and Trivalent Transition Metal Ions with Schiff Base as Primary Ligand
}

\author{
Abdussalam Ali Maihub ${ }^{1 *}$, Faten Suliman Alassbaly², Marei Mailoud El-Ajaily², \\ Abdunnaser Mohamed Etorki ${ }^{1}$ \\ ${ }^{1}$ Chemistry Department, Faculty of Science, Tripoli University, Tripoli, Libya \\ ${ }^{2}$ Chemistry Department, Faculty of Science, Benghazi University, Benghazi, Libya \\ Email: ${ }^{*}$ maihuba@yahoo.com, ${ }^{*}$ melajaily@yahoo.com
}

Received 14 April 2014; revised 15 May 2014; accepted 14 June 2014

Copyright (C) 2014 by authors and Scientific Research Publishing Inc.

This work is licensed under the Creative Commons Attribution International License (CC BY). http://creativecommons.org/licenses/by/4.0/

\section{(c) (i) Open Access}

\begin{abstract}
New mixed ligand chelates synthesized from di- and trivalent metal ions ( $\mathrm{Cr}, \mathrm{Co}, \mathrm{Ni}$, and $\mathrm{Cu}$ ions) and Schiff base $\left(L^{1}\right)$ resulted from the condensation of 4-dimethylaminobenzaldehyde with 2 -aminophenol as primary ligand, whereas 2-nitroaniline $\left(\mathrm{L}^{2}\right)$ represents the secondary ligand in a molar ratio of $M: L^{1}: L^{2}$ [1:1:1]. The synthesized Schiff base and chelates have been characterized by using several tools, such as, elemental analysis, molar conductivity, magnetic moment measurements, infrared and electronic spectra. The mass spectra of the ligands and Ni(II) chelate were used to justify the process of modification, as well as, the electron paramagnetic resonance spectrum which was carried out for $\mathrm{Cu}$ (II) chelate all in order to elucidate the chemical and geometrical structure of the chelates. On the basis of the obtained data, the geometry of the products was proposed for all the chelates.
\end{abstract}

\section{Keywords}

Schiff Base, 2-Nitroaniline, Chelates, 4-Dimethylaminobenzaaldehyde, 2-Aminophenol, Physiochemical Techniques

\section{Introduction}

The chemistry of the complex or chelate, concerning “coordination chemistry”, evoked considerable attention in

${ }^{*}$ Corresponding author.

How to cite this paper: Maihub, A.A., Alassbaly, F.S., El-Ajaily, M.M. and Etorki, A.M. (2014) Modification on Synthesis of Mixed Ligand Chelates by Using Di- and Trivalent Transition Metal Ions with Schiff Base as Primary Ligand. Green and Sustainable Chemistry, 4, 103-110. http://dx.doi.org/10.4236/gsc.2014.43015 
the recent years to study the structures which consist of Lewis acid (central metal) and Lewis base (ligands) through chemical bonding. Some metal chelates are formed virtually irreversibly and many are bound together by bonds that are quite stable and strong [1]. Schiff bases are of the most widely used organic moiety or compounds which are endowed with wild rang of interesting application fields. They have been shown to exhibit a broad range of biological activities including antimicrobial, antiviral and antipyretic properties [2]. The chelates of metal ions: $\mathrm{Co}(\mathrm{II}), \mathrm{Ni}(\mathrm{II}), \mathrm{Cu}(\mathrm{II}), \mathrm{Zn}(\mathrm{II}), \mathrm{Cd}(\mathrm{II})$ and $\mathrm{Hg}(\mathrm{II})$ with a Schiff base derived from benzofuran-2carbohydrazide with 3,4,5-trimethoxy-benaldehyde as primary ligand and malonyldihydrazide as secondary ligand have been synthesized. The geometrical structures of the chelates have been proposed in the light of elemental analyses, molar conductance measurements, infrared, electronic, proton nuclear magnetic resonance, and mass and electron spin resonance spectra. The antibacterial activity of the compounds was screened on some pathogenic bacteria [3]. Mixed ligand of $\mathrm{Ni}(\mathrm{II}), \mathrm{Cu}(\mathrm{II})$ and $\mathrm{Zn}(\mathrm{II})$ chelates of nicotinanilide and thiocyanate was prepared. The chelates were investigated by several physiochemical techniques. The chelates are of 1:2 [M:L] ratio and are non-electrolytes nature. A distorted tetrahedral structure was proposed for all chelates [4].

Schiff bases with nitro group as substituent have been investigated in order to elucidate the coordination compounds whether the coordination exist through the oxygen or nitrogen atoms of nitro group. In this aspect, they have been found that nitro group can coordinate through oxygen side if there areno competing sites for the interaction. The coordination has been justified by bands of infrared spectra of the chelates [5]-[7].

Despite the extensive use of Schiff bases in different applications within the region of pure chemistry, reports of detailed physiochemical investigation on coordination compounds are rather scanty. The aim of this work is to determine mixed ligands in which part of the ligands represent Schiff base. It is believed that this study would add to the present knowledge in coordination chemistry. This current experiment therefore provides some scientific justification for the utilization of chemicals useful for researchers in inorganic chemistry field [8]. So the present study will describe the synthesis of the Schiff base which used as primary ligand with pure 2-nitroaniline as secondary ligand in variable mixed ligand chelates with $\mathrm{Co}(\mathrm{II}), \mathrm{Ni}(\mathrm{II}), \mathrm{Cu}(\mathrm{II})$ and $\mathrm{Cr}(\mathrm{III})$ ions and to investigate the geometrical structures of the chelates.

\section{Experimental}

\subsection{Material and Methods}

All chemicals and reagents used in this investigation are of pure grade (BDH or Aldrich). include; 4-dimethylaminobenzaldehyde, 2-nitroaniline, 2-aminophenol, $\mathrm{CrCl}_{3} \cdot 6 \mathrm{H}_{2} \mathrm{O}, \mathrm{CoCl}_{2} \cdot 6 \mathrm{H}_{2} \mathrm{O}, \mathrm{NiCl}_{2} \cdot 6 \mathrm{H}_{2} \mathrm{O}, \mathrm{CuCl}_{2} \cdot 2 \mathrm{H}_{2} \mathrm{O}$, DMSO, DMF, $\mathrm{NH}_{4} \mathrm{OH}, \mathrm{CH}_{3} \mathrm{CH}_{2} \mathrm{OH}$ and double distilled water.

The Schiff base and the chelates were subjected to elemental analysis using 2400-CHN elemental analyzer. The molar conductivity of the chelates was measured in DMF solvent using digital conductivity meter CMD650, at chemistry department, Benghazi University, Benghazi, Libya. The infrared spectra were carried out applying KBr disc technique using IFS-25 DPUS/IR spectrometer. The electronic spectra were measured in DMF solvent by using a Perkin-Elmer lambda- $4 \beta$ spectrophotometer. The mass spectra also carried out by using Shimadzu QP-2010 Plus. The electron paramagnetic resonance spectrum was recorded by using EMX ESR spectrometer (Bruker) 1998Y. All previous tools and analysis were done at micro-analytical centre, Cairo University, Giza, Egypt.

\subsection{Synthesis of the Schiff Base}

The Schiff base was synthesized by dissolving 4-dimethylaminobenz aldehyde ( $0.01 \mathrm{~mol} ; 1.49 \mathrm{~g}$ ) and same moles of 2-aminophenol in $50 \mathrm{ml}$ of ethanol. The mixture was heated and stirred magnetically for 2 hrs. Yellow crystals will form then filtered, washed, dried and recrystallized from hot methanol to give pure crystals in excellent yield of $85 \%$.

\subsection{Synthesis of Mixed Ligand Chelates}

A general procedure has been adopted for the synthesis of chelates in mild basic media. Ethanolic solutions (25 $\mathrm{ml}$ ) of 0.01 moles of the salts $\left[\mathrm{CrCl}_{3} \cdot 6 \mathrm{H}_{2} \mathrm{O} ; 2.67 \mathrm{~g}, \mathrm{CoCl}_{2} \cdot 6 \mathrm{H}_{2} \mathrm{O} ; 2.38 \mathrm{~g}, \mathrm{NiCl}_{2} \cdot 6 \mathrm{H}_{2} \mathrm{O} ; 2.37 \mathrm{~g}\right.$, or $\mathrm{CuCl}_{2} \cdot 2 \mathrm{H}_{2} \mathrm{O}$; $1.71 \mathrm{~g}$ ] were added to $25 \mathrm{ml}$ of solution containing 0.01 moles of each of Schiff base and 2-nitroaniline. Few drops of ammonia solution (10\%) were added to bring the mixture up to $\mathrm{pH} \cong 6-7$ at which the precipitate will 
start to appear. The mixtures were refluxed for 3hrs. The obtained chelates of characteristic colors were filtered off, washed several times with hot ethanol and dried. The yields are shown in Table 1.

\section{Results and Discussion}

The reactions of the ligands $\left(\mathrm{L}^{1}, \mathrm{~L}^{2}\right)$ with the metal ions under the investigation yield chelates of the type $\left[\mathrm{M}\left(\mathrm{L}^{1} \mathrm{~L}^{2}\right)(\mathrm{OH})_{\mathrm{x}}\left(\mathrm{H}_{2} \mathrm{O}\right)_{\mathrm{y}}\right] \cdot \mathrm{nH}_{2} \mathrm{O}$, where $\mathrm{n}$ represents hydrated water molecules (as shown in Table 1 ). The reactions can be represented by equations as followed.

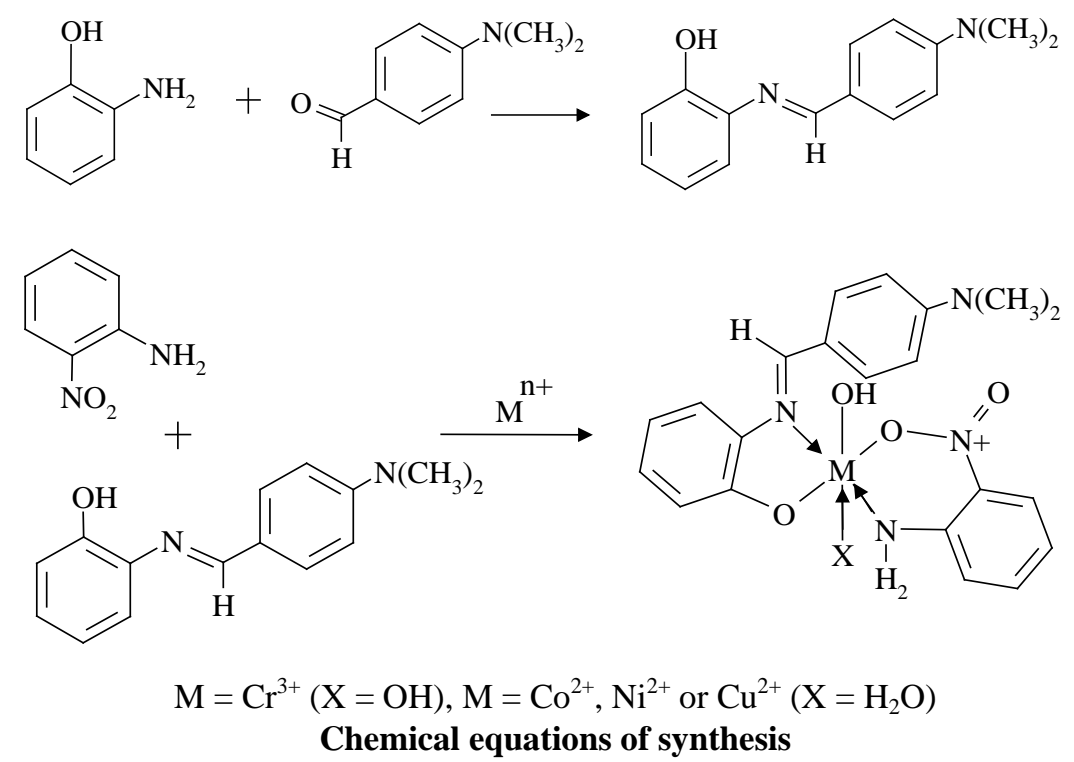

\subsection{Microanalyses and Molar Conductance Measurements}

The CHN elemental analysis data of the synthesized mixed ligand chelates as shown in (Table 1) exhibit the formation of 1:1:1 $\left[\mathrm{M}: \mathrm{L}^{1}: \mathrm{L}^{2}\right]$ ratio. It was found that the theoretical values are in a good agreement with the found data. The purity of the Schiff base and mixed ligand chelates were tested by TLC and CHN elemental analyses. The molar conductance values of DMF solutions of the chelates of the present study lie in the range $3.55-14.88 \mathrm{ohm}^{-1} \cdot \mathrm{cm}^{2} \cdot \mathrm{mole}^{-1}$ confirm the existence of non-electrolytic nature [9].

\subsection{Infrared Spectral Studies}

Due to the chelate nature of the IR spectra of the mixed ligand chelates with varying intensities it is very difficult to assign all the bands attempts, however, have been made to assign some of the important vibrational stretching bands on the basis of the reports available in the literature. The infrared spectral results of the ligands and their $\mathrm{Cr}(\mathrm{III}), \mathrm{Co}(\mathrm{II}), \mathrm{Ni}(\mathrm{II})$ and $\mathrm{Cu}(\mathrm{II})$, mixed ligand chelates were listed in (Table 2). The spectra of the mixed ligand chelates exhibit bands in the range of $3408-3487 \mathrm{~cm}^{-1}$ analogous to the presence of water molecules as hydrated and coordinated [10]. Meanwhile, the same spectra show bands in the range of $1597-1600$ $\mathrm{cm}^{-1}$ assigned to $v(\mathrm{HC}=\mathrm{N})$ vibration, the shifting of these bands to low frequency comparing to the Schiff base $\left(\mathrm{L}^{1}\right)$ confirmed the participation of this group in chelation through nitrogen atom [11]. The other coordination sites of which can take a part in coordination are $\mathrm{NH}_{2}$ and $\mathrm{NO}_{2}$ groups, the strong evidence of sharing of these groups can be seen from the position of the bands at 3349 and $1507 \mathrm{~cm}^{-1}$, respectively in the spectrum of 2-nitroaniline $\left(\mathrm{L}^{2}\right)$.

The changing of the $\mathrm{NH}_{2}$ group band in the spectra of the mixed ligand chelates suggest the involvement of this group in chelation through nitrogen atom [12]. The changing of $-\mathrm{NO}_{2}$ group band of the 2-nitroaniline in the spectra of the mixed ligand chelates indicate the involvement of this group in bonding with the metal ions [13]. New bands in the range of $641-748$ and $441-537 \mathrm{~cm}^{-1}$ which are not exist in the free ligands are due to $v(\mathrm{M}-\mathrm{O})$ and $v(\mathrm{M}-\mathrm{N})$ vibrations and the appearance of these bands support participation of oxygen and nitrogen atoms of the azomethine, $\mathrm{NO}_{2}$ and $\mathrm{OH}$ groups of the free ligands in chelation process [14]. 
Table 1. Elemental analyses and related properties of the Schiff base and the chelates.

\begin{tabular}{|c|c|c|c|c|c|c|c|c|c|c|c|}
\hline Ligand/Chelate & $\begin{array}{l}\text { M. } \\
\text { wt }\end{array}$ & colour & $\begin{array}{c}\text { Yield } \\
\text { (\%) }\end{array}$ & $\begin{array}{l}\text { C\% } \\
\text { Calc. }\end{array}$ & $\begin{array}{l}\text { C\% } \\
\text { Exp. }\end{array}$ & $\begin{array}{r}\% \mathrm{H} \\
\text { Calc. }\end{array}$ & $\begin{array}{c}\% \mathrm{H} \\
\text { Exp. }\end{array}$ & $\begin{array}{r}\% \mathrm{~N} \\
\text { Calc. }\end{array}$ & $\begin{array}{l}\% N \\
\text { Exp. }\end{array}$ & $\underset{\mathbf{B M}}{\boldsymbol{\mu}}$ & $\Lambda^{*}$ \\
\hline Schiff base $\left(\mathrm{L}^{1}\right)$ & 240 & $\begin{array}{l}\text { Bright } \\
\text { yellow }\end{array}$ & 85.00 & 75.00 & 72.76 & 6.60 & 4.84 & 11.67 & 12.77 & - & - \\
\hline$\left[\mathrm{Cr}\left(\mathrm{L}^{1} \mathrm{~L}^{2}\right)(\mathrm{OH})_{2}\right] \cdot 6 \mathrm{H}_{2} \mathrm{O}$ & 591 & $\begin{array}{l}\text { Burnt } \\
\text { sienna }\end{array}$ & 74.14 & 42.63 & 42.23 & 3.89 & 3.91 & 9.47 & 9.99 & 3.02 & 9.35 \\
\hline$\left[\mathrm{Co}\left(\mathrm{L}^{1} \mathrm{~L}^{2}\right)(\mathrm{OH})\left(\mathrm{H}_{2} \mathrm{O}\right)\right] \cdot 6 \mathrm{H}_{2} \mathrm{O}$ & 506 & $\begin{array}{l}\text { Burnt } \\
\text { umber }\end{array}$ & 76.45 & 40.90 & 40.26 & 3.73 & 3.13 & 9.09 & 8.37 & 3.79 & 14.88 \\
\hline$\left[\mathrm{Ni}\left(\left[\mathrm{L}^{1} \mathrm{~L}^{2}\right)(\mathrm{OH})\left(\mathrm{H}_{2} \mathrm{O}\right)\right] \cdot 6 \mathrm{H}_{2} \mathrm{O}\right.$ & 579 & $\begin{array}{c}\text { Deep } \\
\text { verdant }\end{array}$ & 71.57 & 43.50 & 43.40 & 3.97 & 3.45 & 9.67 & 9.59 & 2.49 & 5.48 \\
\hline$\left[\mathrm{Cu}\left(\mathrm{L}^{1} \mathrm{~L}^{2}\right)(\mathrm{OH})\left(\mathrm{H}_{2} \mathrm{O}\right)\right] \cdot 3 \mathrm{H}_{2} \mathrm{O}$ & 512 & $\begin{array}{c}\text { Red } \\
\text { umber }\end{array}$ & 78.83 & 49.20 & 48.09 & 4.49 & 4.11 & 10.93 & 10.59 & 1.56 & 3.55 \\
\hline
\end{tabular}

Table 2. Infrared and electronic spectral data of ligands and chelates.

\begin{tabular}{|c|c|c|c|c|c|c|c|}
\hline Ligand/Chelate & $v \mathrm{NO}_{2}$ & $v \mathrm{OH}\left(\mathrm{H}_{2} \mathrm{O}\right)$ & $v \mathrm{NH}_{2}$ & $v \mathrm{C}=\mathrm{N}$ & $v \mathrm{M}-\mathrm{O}$ & $v \mathrm{M}-\mathrm{N}$ & $\mathrm{nm}\left(\mathrm{cm}^{-1}\right)$ \\
\hline Schiff Base $\left(\mathrm{L}^{1}\right)$ & - & 3337 & - & 1588 & - & - & $375(26,666)$ \\
\hline 2-nitroaniline $\left(\mathrm{L}^{2}\right)$ & 1507 & - & 3349 & - & - & - & $\begin{array}{l}282(35,461) \\
318(31,447)\end{array}$ \\
\hline$\left[\mathrm{Cr}\left(\mathrm{L}^{1} \mathrm{~L}^{2}\right)(\mathrm{OH})_{2}\right] \cdot 6 \mathrm{H}_{2} \mathrm{O}$ & 1507 & 3480 & 3375 & 1597 & 746 & 523 & $385(25,974)$ \\
\hline$\left[\mathrm{Co}\left(\mathrm{L}^{1} \mathrm{~L}^{2}\right)(\mathrm{OH})\left(\mathrm{H}_{2} \mathrm{O}\right)\right] \cdot 6 \mathrm{H}_{2} \mathrm{O}$ & 1482 & 3410 & 3300 & 1600 & 641 & 537 & $\begin{array}{l}413(24,213) \\
754(13,263)\end{array}$ \\
\hline$\left[\mathrm{Ni}\left(\mathrm{L}^{1} \mathrm{~L}^{2}\right)(\mathrm{OH})\left(\mathrm{H}_{2} \mathrm{O}\right)\right] \cdot 6 \mathrm{H}_{2} \mathrm{O}$ & 1488 & 3408 & 3316 & 1600 & 748 & 441 & $\begin{array}{l}294(34,014) \\
396(25,253)\end{array}$ \\
\hline$\left[\mathrm{Cu}\left(\mathrm{L}^{1} \mathrm{~L}^{2}\right)(\mathrm{OH})\left(\mathrm{H}_{2} \mathrm{O}\right)\right] \cdot 3 \mathrm{H}_{2} \mathrm{O}$ & 1508 & 3487 & 3347 & 1597 & 746 & 521 & $\begin{array}{l}387(25,840) \\
797(12,547)\end{array}$ \\
\hline
\end{tabular}

\subsection{Mass Spectra of the Ligands and Nickel(II) Chelate}

The mass spectral fragmentations of the Schiff base $\left(\mathrm{L}^{1}\right), 2$-nitroaniline $\left(\mathrm{L}^{2}\right)$ and $\mathrm{Ni}(\mathrm{II})$ chelate are shown in (Table 3, Figure 1 and Scheme 1). The peak at $\mathrm{m} / \mathrm{e}^{+}=238$ analogous to $\mathrm{C}_{15} \mathrm{H}_{14} \mathrm{~N}_{2} \mathrm{O}^{+}$. Meanwhile, another peak at $\mathrm{m} / \mathrm{e}^{+}=195$ is equal the formula $\mathrm{C}_{13} \mathrm{H}_{9} \mathrm{NO}^{+}$. The structure $\mathrm{C}_{12} \mathrm{H}_{7} \mathrm{O}^{+}$is analogous to peak at $\mathrm{m} / \mathrm{e}^{+}=167$. Meanwhile, the last peak at $\mathrm{m} / \mathrm{e}^{+}=64$ is attributing to $\mathrm{C}_{5} \mathrm{H}_{4}{ }^{+}$. The base peak of 2-nitroaniline $\left(\mathrm{C}_{6} \mathrm{H}_{6} \mathrm{~N}_{2} \mathrm{O}_{2}\right)$ at m/e+ 138 due to the original molecular weight. The peak at $\mathrm{m} / \mathrm{e}^{+}=122$ is analogous to the loss of oxygen atom from the compound. The loss of one nitrogen and one oxygen atoms give a peak at m/e+ $=92$. The peak at $\mathrm{m} / \mathrm{e}^{+}=66$ due to loss of $\mathrm{CN}$. The same spectrum shows a peak at $\mathrm{m} / \mathrm{e}^{+}=39$ corresponding to loss of two carbon atoms and three hydrogen atoms from the free compound. A peak at mle $+=27$ is attributed to loss of carbon atom.

The only mass spectrum of the nickel chelate was done to seize the differences. The spectra shows a molecular ion peak at $\mathrm{m} / \mathrm{e}^{+}=429$, correspond to $\left[\mathrm{Ni}\left(\mathrm{C}_{15} \mathrm{H}_{16} \mathrm{NO}\right)\left(\mathrm{C}_{6} \mathrm{H}_{6} \mathrm{~N}_{2} \mathrm{O}_{2}\right)(\mathrm{OH})\left(\mathrm{H}_{2} \mathrm{O}\right)\right]^{+} \cdot \mathrm{H}_{2} \mathrm{O}$. Whereas, the peak at $\mathrm{m} / \mathrm{e}^{+}=253$ analogues to $\left[\mathrm{Ni}\left(\mathrm{C}_{13} \mathrm{H}_{9} \mathrm{NO}_{2}\right]\right.$. The peak at $\mathrm{m} / \mathrm{e}^{+}=119$ due to $\mathrm{C}_{7} \mathrm{H}_{5} \mathrm{NO}$. The peak appeared at $\mathrm{m} / \mathrm{e}^{+}=$ 83 attributed to $\mathrm{C}_{4} \mathrm{H}_{5} \mathrm{NO}$. The last peak at $\mathrm{m} / \mathrm{e}^{+}=57$ is corresponding to $\mathrm{C}_{3} \mathrm{H}_{5} \mathrm{NO}^{+}$.

\subsection{Electronic Spectra and Magnetic Moment Studies}

The electronic spectral results of the ligands and their mixed ligand chelates and their spectra all are shown in (Table 2). The electronic spectral studies of the mixed ligand chelates of $\mathrm{Cr}(\mathrm{III}), \mathrm{Co}(\mathrm{II}), \mathrm{Ni}(\mathrm{II})$ and $\mathrm{Cu}(\mathrm{II})$ with Schiff base $\left(\mathrm{L}^{1}\right)$ and 2-nitroaniline $\left(\mathrm{L}^{2}\right)$ were carried out in DMF solvent. The spectra of the ligands exhibits $\pi \rightarrow$ $\pi^{*}$ (phenyl rings) and $\mathrm{n} \rightarrow \pi^{*}(\mathrm{HC}=\mathrm{N})$ transitions [15] [16]. For Co(II) chelate, the electronic spectral results display two bands at $413 \mathrm{~nm}\left(24,213 \mathrm{~cm}^{-1}\right)$ and $754 \mathrm{~nm}\left(13,263 \mathrm{~cm}^{-1}\right)$ assigned to ${ }^{4} \mathrm{~T}_{1} \mathrm{~g}(\mathrm{~F}) \rightarrow{ }^{4} \mathrm{~T}_{2} \mathrm{~g}(\mathrm{~F})$ and ${ }^{4} \mathrm{~T}_{1} \mathrm{~g}(\mathrm{~F})$ $\rightarrow{ }^{4} \mathrm{~T}_{1} \mathrm{~g}(\mathrm{P})$ transitions, respectively in octahedral fields. The intensity of the obtained bands and its magnetic moment value (3.79 BM) support the structures [17].

The spectrum of $\mathrm{Ni}(\mathrm{II})$ chelate shows two bands at $294 \mathrm{~nm}\left(34,014 \mathrm{~cm}^{-1}\right)$ and $396 \mathrm{~nm}\left(25,253 \mathrm{~cm}^{-1}\right)$ corresponding to ${ }^{3} \mathrm{~A}_{2} \mathrm{~g}(\mathrm{~F}) \rightarrow{ }^{3} \mathrm{~T}_{2} \mathrm{~g}(\mathrm{~F})$ and ${ }^{3} \mathrm{~A}_{2} \mathrm{~g}(\mathrm{~F}) \rightarrow{ }^{3} \mathrm{~T}_{1} \mathrm{~g}(\mathrm{P})$ transitions. Based on the nature of the bands and the magnetic moment of the chelate (2.49 BM), an octahedral geometry was proposed [18]. The spectrum of $\mathrm{Cu}(\mathrm{II})$ 
chelate reveals two bands at $387 \mathrm{~nm}\left(25,840 \mathrm{~cm}^{-1}\right)$ and $797 \mathrm{~nm}\left(12,547 \mathrm{~cm}^{-1}\right)$ due to ${ }^{2} \mathrm{Eg} \rightarrow{ }^{2} \mathrm{~T}_{2} \mathrm{~g}$ transitions. The intensity of the bands and the magnetic moment value (1.56 BM) also suggest the octahedral structure [19]. In case of $\mathrm{Cr}(\mathrm{III})$ chelate, the spectrum exhibits a band at $385 \mathrm{~nm}\left(26,178 \mathrm{~cm}^{-1}\right)$ analogous to ${ }^{4} \mathrm{~A}_{2} \mathrm{~g}(\mathrm{~F}) \rightarrow{ }^{4} \mathrm{~T}_{2} \mathrm{~g}(\mathrm{~F})$ transitions in agreement with the magnetic moment value (3.02 BM) and the strength of the bands to support the existence of an octahedral [20].

Table 3. Mass spectral fragmentation of the ligands and Ni(II) chelate.

\begin{tabular}{|c|c|c|}
\hline Compound & Fragmented ions & $\mathbf{m} / \mathbf{e}+$ values \\
\hline $\mathrm{C}_{15} \mathrm{H}_{16} \mathrm{~N}_{2} \mathrm{O}\left(\mathrm{L}^{1}\right)$ & $\begin{array}{c}\mathrm{C}_{15} \mathrm{H}_{16} \mathrm{~N}_{2} \mathrm{O} \\
\mathrm{C}_{15} \mathrm{H}_{14} \mathrm{~N}_{2} \mathrm{O}^{+} \\
\mathrm{C}_{13} \mathrm{H}_{9} \mathrm{NO}^{+} \\
\mathrm{C}_{12} \mathrm{H}_{7} \mathrm{O}^{+} \\
\mathrm{C}_{5} \mathrm{H}_{4}^{+}\end{array}$ & $\begin{array}{r}240 \\
238 \\
195 \\
167 \\
64\end{array}$ \\
\hline $\mathrm{C}_{6} \mathrm{H}_{6} \mathrm{~N}_{2} \mathrm{O}_{2}\left(\mathrm{~L}^{2}\right)$ & $\begin{array}{c}\mathrm{C}_{6} \mathrm{H}_{6} \mathrm{~N}_{2} \mathrm{O}_{2} \\
\mathrm{C}_{6} \mathrm{H}_{6} \mathrm{~N}_{2} \mathrm{O}^{+} \\
\mathrm{C}_{6} \mathrm{H}_{6} \mathrm{~N}^{+} \\
\mathrm{C}_{5} \mathrm{H}_{6}^{+} \\
\mathrm{C}_{3} \mathrm{H}_{3}{ }^{+} \\
\mathrm{C}_{2} \mathrm{H}_{3}{ }^{+}\end{array}$ & $\begin{array}{c}138 \\
122 \\
92 \\
66 \\
39 \\
27\end{array}$ \\
\hline$\left[\mathrm{Ni}\left(\mathrm{L}^{1} \mathrm{~L}^{2}\right)(\mathrm{OH})\left(\mathrm{H}_{2} \mathrm{O}\right)\right] \cdot 6 \mathrm{H}_{2} \mathrm{O}$ & $\begin{array}{c}{\left[\mathrm{Ni}\left(\mathrm{C}_{15} \mathrm{H}_{16} \mathrm{NO}\right)\left(\mathrm{C}_{6} \mathrm{H}_{6} \mathrm{NO}_{2}(\mathrm{OH})\left(\mathrm{H}_{2} \mathrm{O}\right)\right]^{+} \cdot \mathrm{H}_{2} \mathrm{O}\right.} \\
{\left[\mathrm{Ni}\left(\mathrm{C}_{13} \mathrm{H}_{9} \mathrm{NO}_{2}\right]^{+}\right.} \\
\mathrm{C}_{7} \mathrm{H}_{5} \mathrm{NO}^{+} \\
\mathrm{C}_{4} \mathrm{H}_{5} \mathrm{NO}^{+} \\
\mathrm{C}_{3} \mathrm{H}_{5} \mathrm{O}^{+}\end{array}$ & $\begin{array}{c}429 \\
253 \\
119 \\
83 \\
57\end{array}$ \\
\hline
\end{tabular}

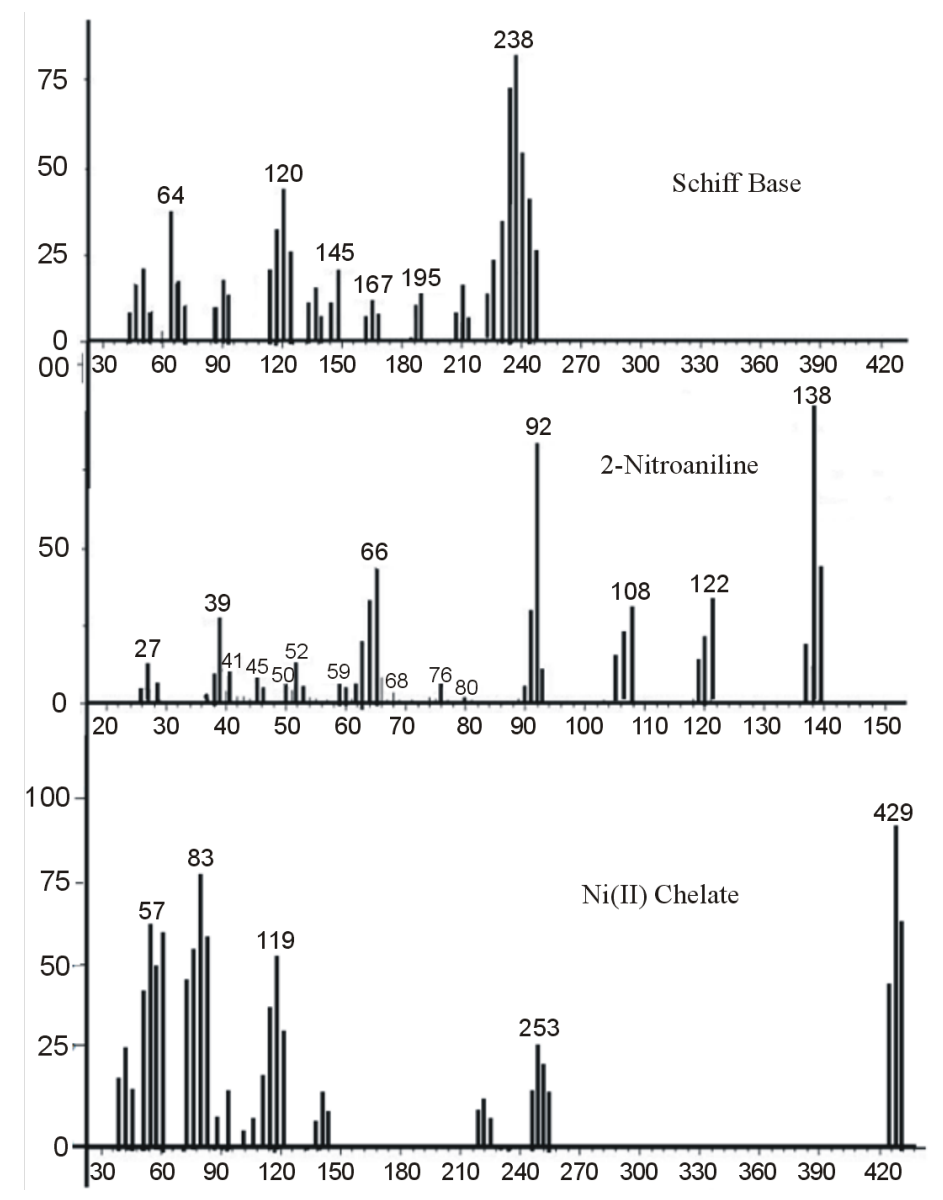

Figure 1. Mass spectra of Schiff base, 2-nitroaniline and Ni(II) chelate. 

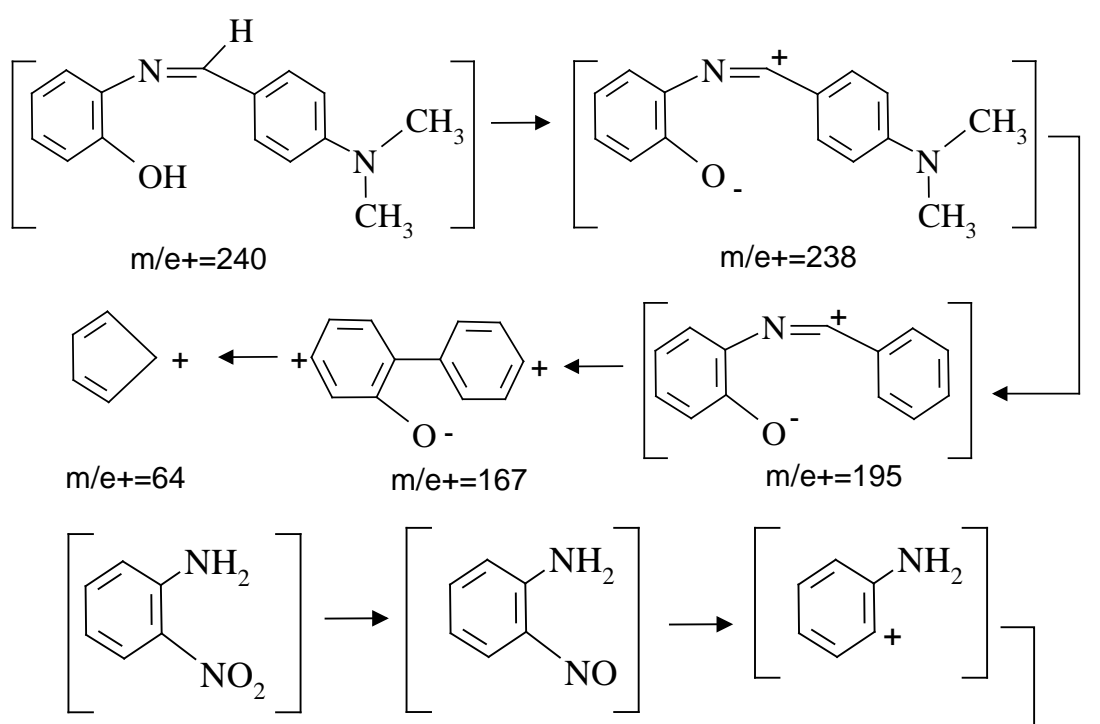

$\mathrm{m} / \mathrm{e}+=138$

$\mathrm{m} / \mathrm{e}+=122$

$\mathrm{m} / \mathrm{e}+=92$

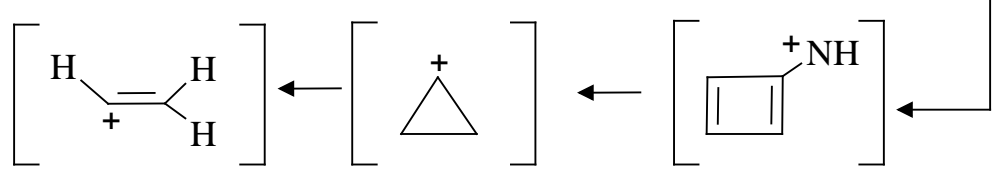

$\mathrm{m} / \mathrm{e}+=27 \quad \mathrm{~m} / \mathrm{e}+=39$

$\mathrm{m} / \mathrm{e}+=66$<smiles></smiles>

$\mathrm{m} / \mathrm{e}+=579$<smiles></smiles>

$2^{\mathrm{O}}$<smiles></smiles>
$\mathrm{m} / \mathrm{e}+=429$

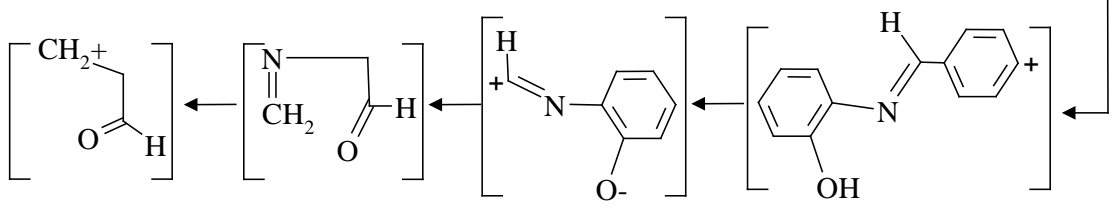

$\mathrm{m} / \mathrm{e}+=57 \quad \mathrm{~m} / \mathrm{e}+=83$

$$
\mathrm{m} / \mathrm{e}+=119
$$

$\mathrm{m} / \mathrm{e}+=253$

\section{Scheme 1. Mass spectra of Schiff base, 2-nitroaniline and Ni(II) chelate.}

\subsection{Electron Paramagnetic Resonance Spectrum (EPR) of Cu(II) Chelate}

The EPR spectrum of the powdered sample of $\mathrm{Cu}(\mathrm{II})$ chelate of the formula $\left[\mathrm{Cu}\left(\mathrm{L}^{1} \mathrm{~L}^{2}\right)(\mathrm{OH})\left(\mathrm{H}_{2} \mathrm{O}\right)\right] \cdot 3 \mathrm{H}_{2} \mathrm{O}(\mathrm{Fig}-$ ure 2) was recorded at room temperature. The $\boldsymbol{g}$-value of this chelate is 2.109. The obtained value deviated from the ideal value (2.0023). Even though there is deviation, still in agreement with the covalent character of metal ligand bonding and confirm the existence of an octahedral structure [21] [22].

\section{Conclusion}

The obtained mixed ligand chelates have been prepared and characterized by known several physiochemical techniques from which endowed data about the Schiff bases as primary ligand can chelate together with bidentate ligand as secondary ligand and ongoing confirm the existence of an octahedral geometry for all mixed 


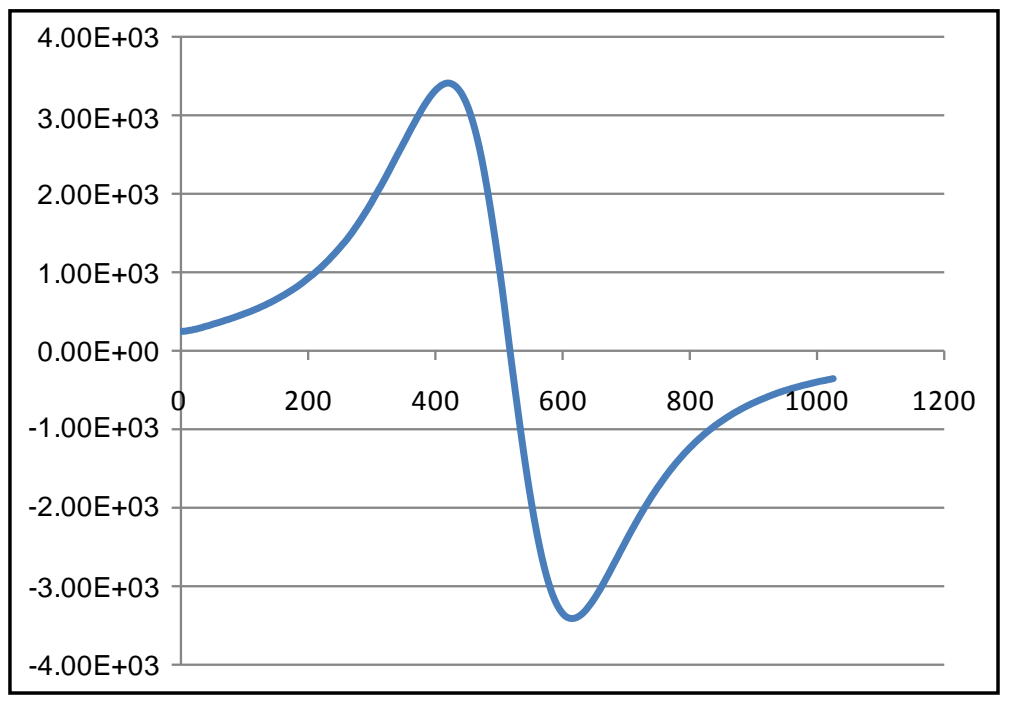

Figure 2. Electron paramagnetic resonance spectrum $\mathrm{Cu}(\mathrm{II})$ chelate.

ligand chelates. The geometrical structures concerning the chelates are proposed in the chemical equations cited before.

\section{References}

[1] Sharma, N., Prakash, R. and Chaturvedi, K. (2012) Spectroscopic and Antimicrobial Studies of Mixed Ligand Complexes of Transition Metal (II) Ions with Nitro Quinoline and Dibenzoyl Methane. Scientific Reviews \& Chemical Communications, 2, 108-114.

[2] Al Zoubi, W. (2013) Biological Activities of Schiff Bases and Their Complexes: A Review of Recent Works. International Journal of Organic Chemistry, 3, 73-95. http://dx.doi.org/10.4236/ijoc.2013.33A008

[3] Halli, H.B., Patilm, V.B., Sumathi, R.B. and Mallikarjan, K. (2012) Synthesis, Characterization and Biological Activity of Mixed Ligand Metal (II) Complexes Derived from Benzofuran-2-Carbohydrazide Schiff Base and Malonyldihydrazide. Der Pharma Chemica, 4, 2360.

[4] Balan, A.M., Ashok, R.F.N., Vasanthi, M., Prabu, R. and Paulraj, A. (2013) Mixed Ligand Complexes of Nickel(II), Copper(II) and Zinc(II) with Nicotinanilide and Thiocyanate. International Journal of Life Science and Pharma Reviews, 3, 67-75.

[5] Shakti, S., Mishra, P.M., Mishra, S.K. and Jha, A.K. (2010) Synthesis and Characterization of Complexes of 2-Hydroxy-3-Nitro Acetophenyl Thiosemicarbazone with Some 3d Series Transition Metals. Asian Journal of Chemistry, 22, 5013-5018.

[6] Vicente, J., Chicote, M. and Martin, J. (1987) Synthesis of o-Nitrophenylplatinum(IV) Complexes; Crystal and Molecular Structure of Dichlorobis(2=nitrophenyl=C'O)platinum(IV). Journal of the Chemical Society, Dalton Transactions, 881-884. http://dx.doi.org/10.1039/dt9870000881

[7] Shivankar, V.S., Vaidya, R.B., Dharwadkar, S.R. and Thakkar, N.V. (2003) Synthesis, Characterization, and Biological Activity of Mixed Ligand Co(II) Complexes of 8-Hydroxyquinoline and Some Amino Acids. Synthesis and Reactivity in Inorganic and Metal-Organic Chemistry, 33, 1597-1622. http://dx.doi.org/10.1081/SIM-120025443

[8] Lakshmi, P.V., Reddy, P.S. and Raju, V.J. (2008) Synthesis and Structure Studies of First Row Transition Metal Complexes of N-(2-Nitro)-Benzilidene-3-Hydrazino Quinoxaline-2-One. Bulletin of the Chemical Society of Ethiopia, 22, 385-390.

[9] Geary, W.J. (1971) The Use of Conductivity Measurements in Organic Solvents for the Characterisation of Coordination Compounds. Coordination Chemistry Reviews, 7, 81-122. http://dx.doi.org/10.1039/dt9870000881

[10] Nakamoto, T.O. (1970) Infrared Spectra of Inorganic and Coordination Compounds. 2nd Edition, Wiley-Interscience, New York.

[11] Sing, B., Narang, K.K. and Srivastava, R. (2002) Synthesis and Reactivity in Inorganic and Metal-Organic Chemistry. 32, 1577

[12] Patil, A.R., Donde, K.J., Raut, S.S., Patil, V.R. and Lokhande, R.S. (2012) Synthesis, Characterization and Biological Activity of Mixed Ligand Co(II) Complexes of Schiff Base 2-Amino-4-nitrophenol-n-salicylidene with Some Amino 
Acids. Journal of Pharmacy Research, 4, 1413-1425.

[13] Vicente, J., Chicote, M.-T. and Martin, J. (1987) Synthesis of o-Nitrophenyl Platinum(IV) Complexes; Crystal and Molecular Structure of Dichlorobis(2-nitro phenyl-C'O)platinum(IV). Journal of the Chemical Society, Dalton Transactions, 881-884.

[14] El-Zweay, R.S., El-Ajaily, M.M., Ben-Gweirif, S.F. and Maihub, A.A. (2013) Preparation, Characterization and Antibacterial Activity of some Mixed Ligand Chelates. Journal of the Chemical Society of Pakistan, 35, 67-71.

[15] Gaur, S. and Sharma, B. (2003) Schiff Base Macrocyclic Ligand Derived from Thiosemicarbazone with Their Spectroscopic and Antimicrobial Studies. Journal of the Indian Chemical Society, 8, 841.

[16] Abuamer, K.M., Maihub, A.A., El-Ajaily, M.M., El-Torki, A.M., Aboukrisha, M.M. and Almagani, M.A. (2014) The Role of Aromatic Schiff Bases in the Dyes Techniques. International Journal of Organic Chemistry, 4, 7-15. http://dx.doi.org/10.4236/ijoc.2014.41002

[17] Maihub, A.A., El-Ajaily, M.M. and El-Hassy, N.A. (2012) Titanium(IV), Chromium(III) and Iron(III) Complexes of Schiff Base Derived from Aldehyde and Primary Amine. International Journal of ChemTech Research, 4, 631-633.

[18] Prasad, R.L., Kushwaha, A., Gautam, B.S. (2009) Mixed Ligand Complexes of $\beta$-Diketonates: Synthesis, Characterization, and FAB Mass Spectral Analysis. Journal of Coordination Chemistry, 62, 2983-2994. http://dx.doi.org/10.1080/00958970902954102

[19] Halli, M.B. and Ravindra. S. Malipatil. (2011) Synthesis, Characterization and Spectral Studies of Metal (II) Complexes Derived from Benzofuran-2-Carbohydrazide and 2-Acetylthiophene Schiff's Base. Der Pharma Chemica, 3, 146-157.

[20] Issa, Y.M., Al-Ansary, A.L., Sharif, O.E. and El-Ajaily, M.M. (1997) Separation and Spectroscopic Characterization of New Metal Chelates of 8-Arylazo-6-formyl-7-hydroxy-5-methoxy-2-methyl Chromones. Transition Metal Chemistry, 22, 441-446. http://dx.doi.org/10.1023/A:1018546826285

[21] Karidi, K., Garoufis, A., Hadjiliadis, N., Lutz, M., Spek, A. and Reedijk, J. (2006) Synthesis, Characterization, and DNA-Binding Studies of Nitro(oligopyridine)ruthenium(II) Complexes. Inorganic Chemistry, 45, 10282-10292.

[22] Jadhav, S.S., Kolhe, N.H. and Athare, A.E. (2013) Synthesis, and Characterization of Mixed Ligans Complexes of Salicyladoxime, Dimethylglyoxime and Benzoin with $\mathrm{Mn}(\mathrm{II})$ and Their Biological Activity. International Journal of Pharmacy and Biological Sciences, 4, 45-54. 
Scientific Research Publishing (SCIRP) is one of the largest Open Access journal publishers. It is currently publishing more than 200 open access, online, peer-reviewed journals covering a wide range of academic disciplines. SCIRP serves the worldwide academic communities and contributes to the progress and application of science with its publication.

Other selected journals from SCIRP are listed as below. Submit your manuscript to us via either submit@scirp.org or Online Submission Portal.
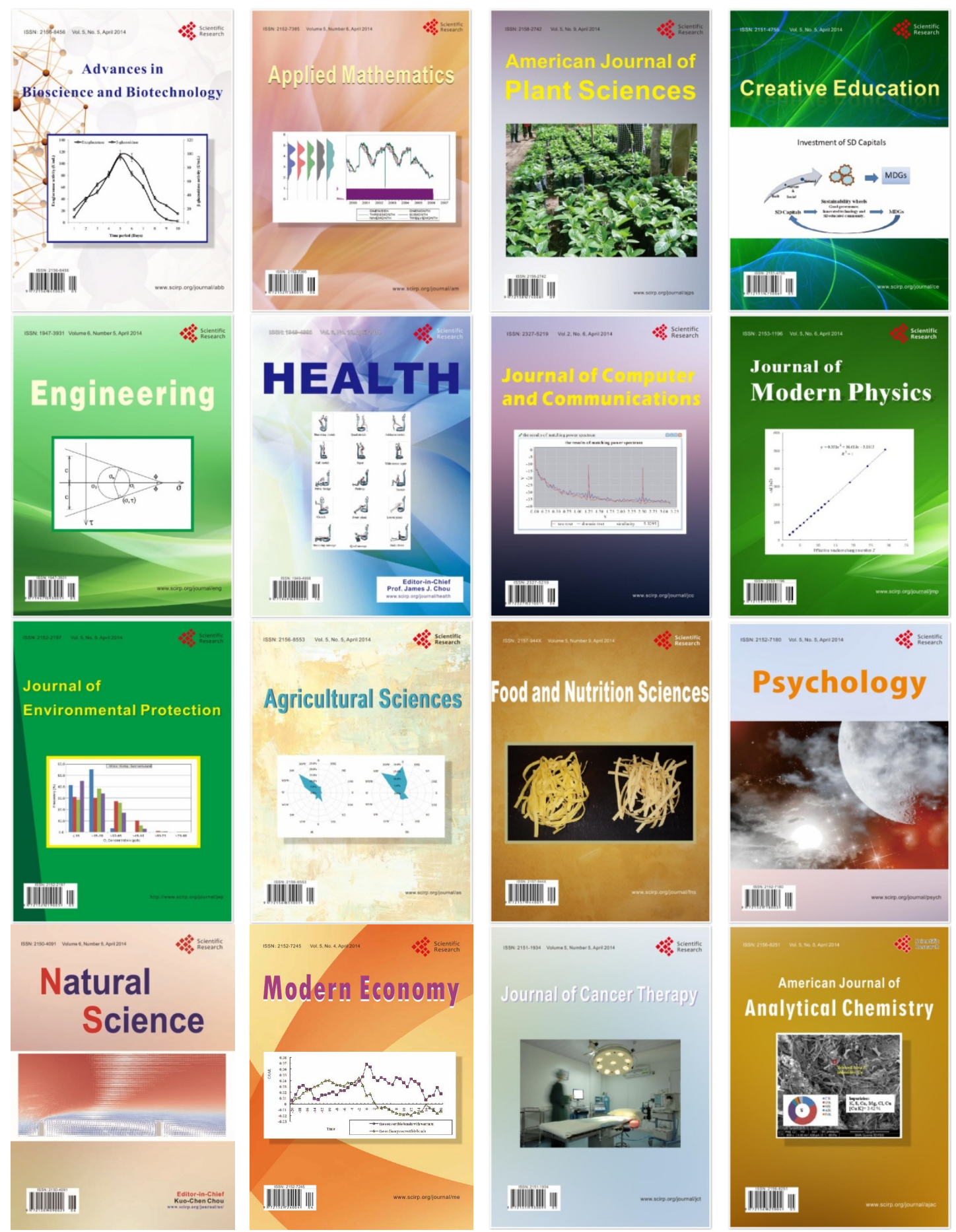